\title{
EFFECTS OF CHIA SEED LEVELS ON QUALITY AND BIO-FUNCTIONAL PROFILE OF STIRRED YOGHURT
}

\author{
O. Ben Moussa*, E. Rouissi, M. Boulares and M. Hassouna \\ Research Unity 'Bio-Preservation and Valorization of Agricultural Products UR13-AGR 02', Higher Institute \\ of Food Industries of Tunisia (ESIAT), Carthage University. Tunisia
}

(Received: 22 February 2020; accepted: 25 May 2020)

\begin{abstract}
Yoghurt is considered as a healthy food. Thus, it could convey functional and bioactive ingredients. Chia seeds are of great interest due to their ability to improve consumer health. In this study, chia seeds were added to stirred yoghurt at different doses $(1.5,3,4.5$, or $6 \%)$. The effects of chia seeds on physicochemical, microbiological, and sensory qualities were assessed during 28 days of refrigerated storage. The results showed that chia seeds slightly decreased post-acidification, the lowest value was obtained in yogurt with $3 \%$ chia seeds $\left(24^{\circ} \mathrm{D}\right)$, but syneresis rose significantly $(\mathrm{P}<0.05)$ when $6 \%$ of chia seeds was added. Furthermore, chia seeds promote viability of yoghurt bacteria, and antioxidant activity reached $62.20 \pm 0.02 \%$ in yoghurt added with $1.5 \%$ chia seeds. However, proteolysis is not affected. The effects of chia seeds were not dose dependent as $4.5 \%$ and $6 \%$ did not follow trend. These findings were affirmed by sensory characteristics. Thus, stirred yoghurt containing 1.5 or $3 \%$ of chia seeds proved to be the most adequate choices.
\end{abstract}

Keywords: chia, dose, yoghurt, quality, bio-functional

Yoghurt is one of the most popular fermented dairy products owing to its sensory characteristics and nutritional and health benefits (DAS et al., 2019). It promotes gut health and has a hypocholesterolemic action (FARKHANDAH et al., 2019; SHAFI et al., 2019). Actually, a vast array of yoghurts exists to suit all palates, with multiple features. Bioactive compounds such as probiotics and prebiotics are usually added to yoghurts to enhance functionality, quality, and therapeutic properties (CRUZ et al., 2013). On the other hand, fruit fibre, pulp, or seed extract supplementations were only recently tested (HADJimBeI et al., 2020; KHALEDABAD et al., 2020) to promote either yoghurt benefits and/or quality.

Seed from Salvia hispanica L. or more commonly known as chia is a traditional food in Central and South America. Currently, it is widely consumed for various health benefits, especially in maintaining healthy serum lipid level. This effect is enhanced by the presence of phenolic acid and omega 3/6 oil in chia seed (MUÑoz-TÉBAR et al., 2019). Chia also promotes glycaemic index and weight loss due to high dietary fibre content (JENKINs et al., 2016). Human dietary chia is usually consumed raw in salads as sprouts or seeds and added to beverages. Recently, it was also used in some foods as ingredient (Alves PIREs et al., 2020; PIGNI et al., 2020). The use of chia as an ingredient in the processing of widely consumed foods, such as dairy products, appears to be a promising approach. However, to the best of our knowledge, no study has been done on the utilisation of chia seeds in yogurt.

So, the objective of the current work was to evaluate the effect of chia seed fortification at different doses $(0,1.5,3,4.5,6 \%)$ on the quality (biochemical, bio-functional, microbiological, and sensory parameters) of stirred yoghurt during 28 days of refrigerated storage.

* To whom correspondence should be addressed.

E-mail: olfajameel@yahoo.fr 


\section{Materials and methods}

\subsection{Stirred yoghurt production}

Non-fat milk was pasteurised at $95{ }^{\circ} \mathrm{C}$ for $3 \mathrm{~min}$. Then it was rapidly cooled down to $43 \pm 1$ ${ }^{\circ} \mathrm{C}$ and divided into five batches. Milks were fermented by direct inoculation with mixed starter culture at 3\% (YS 131 with Streptococcus thermophilus and Lactobacillus bulgaricus from DSM dairy cultures, USA). The inoculated milk was incubated at $43{ }^{\circ} \mathrm{C}$ until the $\mathrm{pH}$ reached 4.6 and acidity reached $75^{\circ} \mathrm{D}$, and then cooled and stored at $4{ }^{\circ} \mathrm{C}$. Thereafter, chia seeds were added to each batch at $0,1.5 \%, 3 \%, 4.5 \%$ and $6 \%$. The gel was broken by stirring with a glass rod (10 times clockwise; 10 times anticlockwise). Yoghurts were filled into 100 $\mathrm{ml}$ glass jars and stored at $4{ }^{\circ} \mathrm{C}$ for 28 days. Dornic acidity, $\mathrm{pH}$, syneresis, proteolytic activity, antioxidant activity, and lactic acid bacterium counts were determined after $24 \mathrm{~h}$ of production and each week for 4 weeks of refrigerated storage. Sensory measurements were evaluated at the beginning and on the $14^{\text {th }}$ and $28^{\text {th }}$ days of storage.

\subsection{Yoghurt analysis}

1.2.1. Post-acidification. Post-acidification was evaluated by measurement of $\mathrm{pH}$ and Dornic acidity of yoghurt (expressed as degree Dornic).

1.2.2. Syneresis. The gel was stirred at $4{ }^{\circ} \mathrm{C}$ for $60 \mathrm{~s}$ and centrifuged for $20 \mathrm{~min}$ at $12075 \mathrm{~g}$ in an ultracentrifuge (Beckman USA). Syneresis (\%) was calculated as the mass of the separated serum from the gel after centrifugation, in relation to the total mass of gel that was centrifuged (KHALEDABAD et al., 2020).

1.2.3. Yoghurt bacteria enumeration. The counts of Streptococcus salivarius subsp. thermophilus and Lactobacillus delbruekii subsp. bulgaricus were determined at $37^{\circ} \mathrm{C}$ and $24 \mathrm{~h}$ using M17 and MRS medium, respectively (DownES \& ITO, 2001). The results were expressed as CFU ml-1 .

1.2.4. Proteolytic activity. The proteolytic activity of the yoghurt was determined using the OPA method. The procedure was described by DonKOR and co-workers (2005).

1.2.5. Antioxidant activity. Antioxidant activity was evaluated following DPPH assay according to the procedure by HANATO and co-workers (1988).

1.2.6. Sensory evaluation. Throughout the storage period at $4^{\circ} \mathrm{C}\left(1^{\text {st }}, 14^{\text {th }}\right.$, and $28^{\text {th }}$ day), the sensory properties of experimental yoghurts were evaluated according to the method described by JANIASKI and co-workers (2016). Jury of panellists consisted of 20 trained members ( 8 male and 12 female, aged between 24 and 45 years). The trained panellists were students and professors from the Tunisian Higher Institute of Food Industry. The test was performed inside a uniformly illuminated room, at approximately $25{ }^{\circ} \mathrm{C}$. The obtained yoghurts were coded with a random six-digit number and served to panellists in a randomised order. The main descriptors used to evaluate appearance, taste, and texture were sweet taste, bitter taste, mouth feel, granular texture, whey exudation, white colour, and overall acceptance, on a 9-point scale (DA SILvA et al., 2018). 


\subsection{Statistical analysis}

The obtained data were statistically evaluated using one-way analysis of variance (ANOVA) with Ducan's test for mean comparison to highlight significant differences $(\mathrm{P}<0.05)$ among yoghurt samples. All experiments were carried out in triplicate.

\section{Results and discussion}

\subsection{Post-acidification and syneresis}

Table 1 shows the changes in $\mathrm{pH}$ values, Dornic acidity, and syneresis of stirred yoghurt supplemented with different concentrations $(0,1.5,3,4.5$, and $6 \%)$ of chia seeds, stored at $4{ }^{\circ} \mathrm{C}$ for 28 days.

Table1. Variations in post-acidification and syneresis of stirred yoghurt containing various doses of chia seeds $(0,1.5,3,4.5$, and $6 \%)$ for 28 days of storage at $4{ }^{\circ} \mathrm{C}$

\begin{tabular}{|c|c|c|c|c|c|c|}
\hline \multirow[t]{2}{*}{ Parameters } & \multirow{2}{*}{$\begin{array}{l}\text { Chia seeds } \\
\text { doses }(\%)\end{array}$} & \multicolumn{5}{|c|}{ Storage period (day) } \\
\hline & & 1 & 7 & 14 & 21 & 28 \\
\hline \multirow[t]{5}{*}{$\mathrm{pH}$} & 0 & $5.05 \pm 0.03^{\mathrm{a}}$ & $4.89 \pm 0.008^{\mathrm{a}}$ & $4.70 \pm 0.04^{\mathrm{a}}$ & $4.28 \pm 0.03^{b}$ & $4.09 \pm 0.01^{\mathrm{a}}$ \\
\hline & 1.5 & $5.30 \pm 0.01^{\text {a.b }}$ & $5.21 \pm 0.02^{\mathrm{c}}$ & $5.01 \pm 0.03^{\mathrm{b}}$ & $4.77 \pm 0.03^{\mathrm{b}}$ & $4.35 \pm 0.02^{\mathrm{b}}$ \\
\hline & 3 & $5.26 \pm 0.08^{\mathrm{a}}$ & $5.20 \pm 0.14^{\mathrm{c}}$ & $5.01 \pm 0.01^{\mathrm{b}}$ & $4.79 \pm 0.028^{b}$ & $4.43 \pm 0.04^{\mathrm{b}}$ \\
\hline & 4.5 & $5.51 \pm 0.3^{\mathrm{a} \cdot \mathrm{b}}$ & $5.03 \pm 0.18^{\mathrm{b}}$ & $4.79 \pm 0.12^{\mathrm{a}}$ & $4.38 \pm 0.01^{\mathrm{b}}$ & $4.12 \pm 0.02^{\mathrm{a}}$ \\
\hline & 6 & $5.82 \pm 0.004^{\mathrm{b}}$ & $5.58 \pm 0.03^{\mathrm{d}}$ & $5.37 \pm 0.02^{\mathrm{c}}$ & $5.23 \pm 0.02^{\mathrm{a}}$ & $4.95 \pm 0.02^{\mathrm{c}}$ \\
\hline \multirow{5}{*}{$\begin{array}{l}\text { Dornic } \\
\text { acidity } \\
\left({ }^{\circ} \mathrm{D}\right)\end{array}$} & 0 & $81 \pm 2.08^{c}$ & $87 \pm 0.05^{\mathrm{d}}$ & $96 \pm 0.57^{\mathrm{d}}$ & $100.33 \pm 0.33^{b}$ & $111 \pm 1.15^{\mathrm{b}}$ \\
\hline & 1.5 & $76.66 \pm 1.20^{\text {b.c }}$ & $80 \pm 0.00^{\mathrm{b}}$ & $86 \pm 1.73^{\mathrm{b}}$ & $97.33 \pm 0.66^{\mathrm{b}}$ & $105.33 \pm 0.45^{\mathrm{a}}$ \\
\hline & 3 & $79.33 \pm 1.20^{\mathrm{c}}$ & $84 \pm 0.12^{\mathrm{c}}$ & $87.66 \pm 1.76^{\text {b.c }}$ & $100.33 \pm 0.60^{b}$ & $103.66 \pm 0.30^{\mathrm{a} . \mathrm{b}}$ \\
\hline & 4.5 & $72.33 \pm 1.85^{\mathrm{b}}$ & $82.33 \pm 0.20^{\text {b.c }}$ & $91.66 \pm 1.20^{\mathrm{c}}$ & $102.66 \pm 0.18^{\mathrm{b}}$ & $108.66 \pm 1.20^{\mathrm{a} . \mathrm{b}}$ \\
\hline & 6 & $66.33 \pm 0.88^{\mathrm{a}}$ & $67.66 \pm 0.057^{\mathrm{a}}$ & $71 \pm 0.57^{\mathrm{a}}$ & $89.33 \pm 2.33^{\mathrm{a}}$ & $103 \pm 2.51^{\mathrm{a}}$ \\
\hline \multirow{5}{*}{$\begin{array}{l}\text { Syneresis } \\
(\%)\end{array}$} & 0 & $63.34 \pm 1.90^{\mathrm{c}}$ & $66.36 \pm 1.78^{\mathrm{c}}$ & $72.2 \pm 0.35^{\mathrm{c}}$ & $77 \pm 0.01^{\mathrm{c}}$ & $84.66 \pm 0.33^{\mathrm{c}}$ \\
\hline & 1.5 & $55.77 \pm 1.40^{\mathrm{b}}$ & $60.09 \pm 1.45^{\mathrm{b}}$ & $62.80 \pm 0.45^{\mathrm{a} . \mathrm{b}}$ & $64.66 \pm 0.33^{\mathrm{a}}$ & $73.66 \pm 0.66^{a . b}$ \\
\hline & 3 & $55.13 \pm 0.47^{\text {a.b }}$ & $55.1 \pm 1.24^{\mathrm{a}}$ & $61.1 \pm 0.20^{\mathrm{a}}$ & $63.9 \pm 0.1^{\mathrm{a}}$ & $71.66 \pm 0.56^{\mathrm{a}}$ \\
\hline & 4.5 & $57.10 \pm 0.27^{\mathrm{b}}$ & $57.6 \pm 0.78^{a . b}$ & $63.93 \pm 0.58^{b}$ & $67.9 \pm 0.49^{b}$ & $76.1 \pm 0.33^{\mathrm{b}}$ \\
\hline & 6 & $60.06 \pm 0.09^{\mathrm{a}}$ & $67 \pm 0.57^{\mathrm{c}}$ & $72.46 \pm 1.57^{\mathrm{c}}$ & $81 \pm 0.01^{\mathrm{d}}$ & $90.66 \pm 0.66^{\mathrm{d}}$ \\
\hline
\end{tabular}

Values in a column with different letters are significantly different at $\mathrm{P}<0.05$. Data means \pm standard deviation ( $\mathrm{n}=3$ ).

Post-acidification of the yoghurts showed an increase over the storage period, $\mathrm{pH}$ values of all yoghurts decreased $(\Delta \mathrm{pH}$ reached 1.39$)$ and Dornic acidity values increased. Indeed, acid-production trend during storage was similar to other research studies (CRUZ et al., 2013). Whereas, a slight increase of $\mathrm{pH}$ was observed in yoghurts supplemented with chia seeds compared to the control. It could be due to some chia fibres diffused in yoghurt gel. Similarly, ESPÍRITO SANTO and co-workers (2012) reported that the $\mathrm{pH}$ of yoghurts with fruit or fruit fibre was higher than that of their respective controls without fruit or fruit fibre. They indicated that lactic acid bacteria in the presence of some fruity products or fibres may reduce their organic acid production.

Syneresis levels increased in all samples over the storage period (Table 1). In fact, the evolution of $\mathrm{pH}$ and Dornic acidity could change global charge of casein, it becomes negative, 
hence, capillary water is kept between casein molecules. These findings are in a good agreement with that of SUPAVITITPATANA and co-workers (2010), who reported that syneresis of yoghurt increases during storage. Moreover, it is noteworthy that syneresis values of yoghurts with chia seeds were significantly lower than those of the control yoghurt $(\mathrm{P}<0.05)$. As shown in Table 1, significant differences existed. The lowest syneresis percentage units (55.77-55.13\%) were observed for 1.5 or $3 \%$ chia seeds yoghurt. Syneresis of yoghurt can be affected by the quantity of proteins and their properties. Indeed, the major polyphenols of chia seed (chlorogenic and caffeic acids) exhibit high reactivity with proteins, which improves the affinity between milk proteins, resulting in their cohesion. DonMEz and co-workers (2017) reported that when yoghurt was enriched with green coffee seeds, containing 4.1 to $11.3 \mathrm{~g}$ of chlorogenic acid/100 g, syneresis was improved by stabilizing the gel structure. Furthermore, both viscosity and syneresis significantly increased in yoghurt supplemented with green tea, which is rich in polyphenols (JEONG et al., 2018). However, the differences in syneresis were not dose dependent. Values obtained with 4.5 or $6 \%$ of chia were higher than those obtained with 1.5 or $3 \%$, but they still remained below the syneresis of the control sample. As a result, high concentration of chia seeds raised the concentration of mucilage, which is able to reduce polyphenolic compounds in fermented milk. Indeed, SALGADO-CRUZ and co-workers (2013) reported that chia mucilage is capable of retaining water, as well as preventing its access inside the seed, so water will not be available to act as a solvent.

\subsection{Yoghurt starter's growth}

As shown in Figure 1A and 1B, yoghurt bacteria counts were up to standards $\left(\geq 10^{9} \mathrm{CFU} \mathrm{m}^{-1}\right.$ for streptococci and $\geq 10^{7} \mathrm{CFU} \mathrm{ml}{ }^{-1}$ for lactobacilli) during the storage. However, Lactobacillus

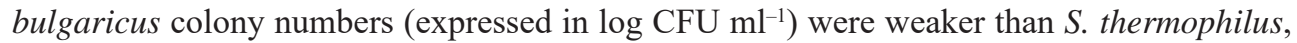
as reported by other authors (CRUZ et al., 2013). In all yoghurt samples, S. thermophilus and L. bulgaricus counts increased slightly for 7 and 14 days, respectively. Then they decreased by the end of the 28 days of refrigerated storage. Indeed, lactic acid exerts an inhibiting effect on S. thermophilus, lowering their count. Lactobacillus bulgaricus and S. thermophilus counts were higher in yoghurts enriched by chia seeds. The same behaviour was previously observed in yoghurts enriched with fruit fibres (EsPíRITO SANTO et al., 2012), which confirms the prebiotic effect of plants, as the viability of yoghurt bacteria can be increased by chlorogenic acid and caffeic acid derived from plant leaf extracts ( $\mathrm{OH}$ et al., 2016).

\subsection{Proteolytic and antioxidant activities}

Main activities (proteolytic and antioxidant) of yoghurt bacteria were assessed during storage (Table 2). Proteolytic activities were regularly monitored during the first two weeks; they ranged between $0.65 \pm 0.03$ to $0.71 \pm 0.01$. They decreased between 14 and 28 days of refrigeration to $0.37 \pm 0.01$. This profile was in line with viability of lactic acid bacteria. Meanwhile, chia seeds did not affect proteolytic activities $(\mathrm{P}>0.05)$. Lactic acid bacteria were characterised by their high demand for essential growth factors, such as peptides and amino acids. Proteinases and peptidases constitute the primary enzymes in lactic acid bacteria responsible for proteolysis in milk proteins as a source of amino acids and nitrogen (CRUZ et al., 2013). 

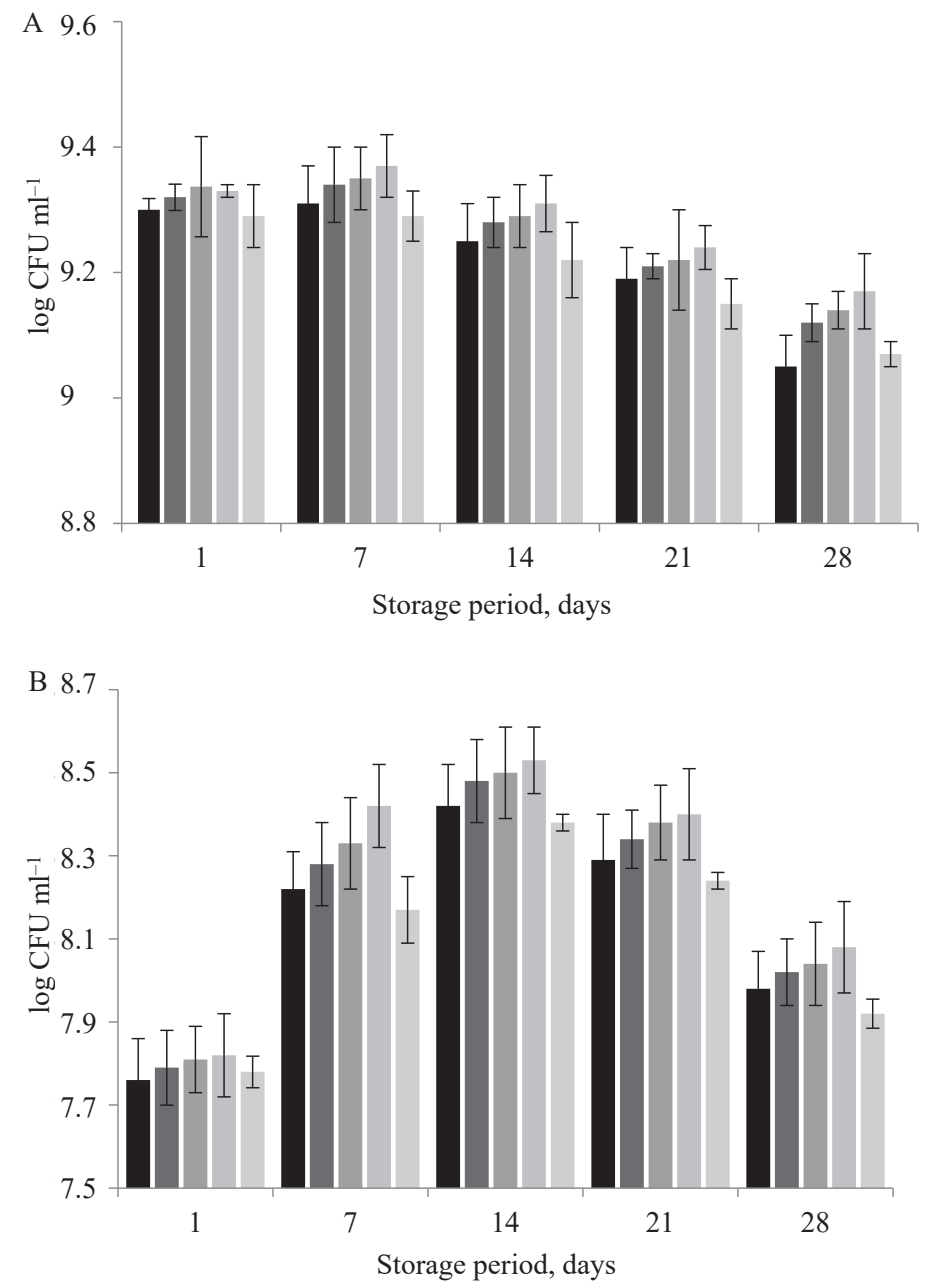

Fig. 1. Viable counts of streptococci (A) and lactobacilli (B) (expressed as $\log \mathrm{CFU} \mathrm{ml}{ }^{-1}$ ) in yoghurt samples (control, enriched with $1.5,3,4.5$, and $6 \%$ of chia seeds) during storage period (first, $7^{\text {th }}, 14^{\text {th }}, 21^{\text {st }}$ and $28^{\text {th }}$ days) ㅁ: Control; ㅁ: $1.5 \%$; : $3 \%$; : $4.5 \%$; : $6 \%$

Regarding the antioxidant activity of all yoghurt samples, the reducing power rose significantly $(\mathrm{P}<0.05)$ during the storage period (Table 2$)$. Yoghurts containing chia seeds had higher reducing power capacity than the control. It reached $62.20 \pm 0.02 \%$ at the $21^{\text {st }}$ day of storage in yoghurt with $1.5 \%$ supplementation. In fact, chia seed contains abundant amounts of polyphenols with antioxidant activity because of the presence of components such as $\alpha$-linolenic acid, chlorogenic acid, and caffeic acid (DE FALCO et al., 2017). These chia seed components showed strong antioxidant and anti-inflammatory effects (MUÑOZ-TÉBAR et al., 2019) that can provide additional bioactive properties to yoghurt. However, highest 
reducing power was obtained for $1.5 \%$ of chia, but when 4.5 or $6 \%$ of chia seeds were added, the reducing power decreased. As a result, as discussed previously, mucilaginous gel formed when high concentration of chia seeds was used that could inhibit the availability of polyphenols in the environment.

Table 2. Changes in proteolytic and antioxidant activities in yoghurts with added chia seeds at different doses $(0,1.5,3,4.5$, and $6 \%)$ for 28 days of storage at $4{ }^{\circ} \mathrm{C}$

\begin{tabular}{|c|c|c|c|c|c|c|}
\hline \multirow[t]{2}{*}{ Activities } & \multirow{2}{*}{$\begin{array}{l}\text { Chia seeds } \\
\text { doses }(\%)\end{array}$} & \multicolumn{5}{|c|}{ Storage period (days) } \\
\hline & & 1 & 7 & 14 & 21 & 28 \\
\hline \multirow{5}{*}{$\begin{array}{l}\text { Proteolytic } \\
\text { activity }\end{array}$} & 0 & $0.69 \pm 0.002^{\mathrm{b}}$ & $0.62 \pm 0.03^{\mathrm{a}}$ & $0.62 \pm 0.03^{a . b}$ & $0.50 \pm 0.03^{\mathrm{b}}$ & $0.38 \pm 0.01^{\mathrm{a}}$ \\
\hline & 1.5 & $0.7 \pm 0.006^{\text {b.c }}$ & $0.65 \pm 0.28 \mathrm{a}$ & $0.66 \pm 0.01^{\mathrm{b}}$ & $0.53 \pm 0.02^{\mathrm{b}}$ & $0.48 \pm 0.02^{\mathrm{c}}$ \\
\hline & 3 & $0.71 \pm 0^{\mathrm{c}}$ & $0.66 \pm 0.31^{\mathrm{a}}$ & $0.66 \pm 0.18^{\mathrm{b}}$ & $0.49 \pm 0.01^{\mathrm{b}}$ & $0.48 \pm 0.008^{\mathrm{c}}$ \\
\hline & 4.5 & $0.69 \pm 0.003^{b}$ & $0.66 \pm 0.20^{\mathrm{a}}$ & $0.63 \pm 0.005^{a . b}$ & $0.5 \pm 0.05^{\mathrm{b}}$ & $0.43 \pm 0.003^{\text {b.c }}$ \\
\hline & 6 & $0.67 \pm 0.003^{\mathrm{a}}$ & $0.65 \pm 0.001^{\mathrm{a}}$ & $0.63 \pm 0.08^{\mathrm{a}}$ & $0.47 \pm 0.04^{\mathrm{a}}$ & $0.37 \pm 0.01^{\mathrm{a}}$ \\
\hline \multirow{5}{*}{$\begin{array}{l}\text { Antioxi- } \\
\text { dant } \\
\text { activity }\end{array}$} & 0 & $6.16 \pm 0.06^{\mathrm{c}}$ & $10.31 \pm 0.06^{\mathrm{c}}$ & $14.45 \pm 0.01^{\mathrm{d}}$ & $16.94 \pm 0.02^{\text {a.d }}$ & $25.95 \pm 0.21^{\mathrm{b}}$ \\
\hline & 1.5 & $32.46 \pm 0.01^{\mathrm{a}}$ & $38.03 \pm 0.01^{\mathrm{a}}$ & $52.49 \pm 0.02^{\mathrm{a}}$ & $62.20 \pm 0.02^{\mathrm{a}}$ & $55.33 \pm 0.03^{\mathrm{a}}$ \\
\hline & 3 & $13.15 \pm 0.01^{\mathrm{b}}$ & $14.34 \pm 0.03^{\mathrm{c}}$ & $16.82 \pm 0.03^{\mathrm{c}}$ & $21.33 \pm 0.12^{\mathrm{a} \cdot \mathrm{b}}$ & $26.18 \pm 0.20^{\mathrm{a} \cdot \mathrm{b}}$ \\
\hline & 4.5 & $6.64 \pm 0.06^{\mathrm{d}}$ & $7.46 \pm 0.08^{\mathrm{d}}$ & $15.76 \pm 0.03^{\mathrm{c}}$ & $17.06 \pm 0.12^{\mathrm{c}}$ & $24.17 \pm 0.18^{b}$ \\
\hline & 6 & $7.58 \pm 0.03^{\mathrm{d}}$ & $7.23 \pm 0.08^{\mathrm{c.d}}$ & $14.69 \pm 0.06^{\mathrm{b} . \mathrm{c}}$ & $17.18 \pm 0.01^{\mathrm{c}}$ & $24.41 \pm 0.03^{\mathrm{b}}$ \\
\hline
\end{tabular}

Values in a column with different letters are significantly different at $\mathrm{P}<0.05$. Data means \pm standard deviation ( $\mathrm{n}=3$ ).

\subsection{Sensory evaluation}

Table 3 represents comparative sensory analysis among yoghurts supplemented with different doses of chia seeds $(0,1.5,3,4.5$, and $6 \%)$ using scoring methodology, after storage for 1,14 , and 28 days. The aroma, colour, odour, and overall aspect rose with chia seed supplementation. High scores were obtained with 1.5 and 3\% at each storage period, but $6 \%$ yoghurt did not follow the trend. Also, addition of 1.5 and $3 \%$ seeds lowered the sourness and whey exudation scores. These findings agree with previous discussion on the yoghurt quality. On the other hand, the seeds gave the yoghurt crunchiness, appreciated by panellists, and it positively affected mouthfeel. The best stirred yoghurt obtained is the one enriched with 1.5 or $3 \%$ of seeds. Likewise, PINTO and co-workers (2018) have used projective techniques, namely shopping list and free word association. These authors reported that functional dairy products could also be considered as foods with striking sensory characteristics due to their superior quality. In this context, it highlighted the need to implement preferred attribute elicitation methodology (SOARES et al., 2020) and multidimensional analysis (TorRes et al., 2017) to evaluate consumer perception of new functional product. 
Table 3. Variations in sensory evaluation of yoghurt containing various doses of chia seeds $(0,1.5,3,4.5$, and $6 \%)$ for 28 days of storage at $4{ }^{\circ} \mathrm{C}$

\begin{tabular}{llcccccccc}
\hline $\begin{array}{l}\text { Stor- } \\
\text { age } \\
\text { period } \\
\text { (days) }\end{array}$ & $\begin{array}{l}\text { Dose } \\
(\%)\end{array}$ & Colour & Aroma & Sourness & Crunch & Mouthfeel & Odour & $\begin{array}{c}\text { Whey } \\
\text { exudation }\end{array}$ & $\begin{array}{c}\text { Overall } \\
\text { aspect }\end{array}$ \\
\hline 1 & 0 & $5.13 \pm 0.4$ & $4.41 \pm 0.2$ & $4.89 \pm 0.24$ & $1 \pm 0.2$ & $2.55 \pm 0.39$ & $4.68 \pm 0.6$ & $3.55 \pm 0.36$ & $4.48 \pm 0.2$ \\
& 1.5 & $5.89 \pm 0.7$ & $5.24 \pm 0.25$ & $4.37 \pm 0.4$ & $3.41 \pm 0.3$ & $3.25 \pm 0.8$ & $5.71 \pm 0.3$ & $3.25 \pm 0.35$ & $5.31 \pm 0.3$ \\
& 3 & $5.96 \pm 0.5$ & $5.2 \pm 0.24$ & $4.93 \pm 0.54$ & $5.17 \pm 0.4$ & $4.43 \pm 0.45$ & $5.28 \pm 0.24$ & $3.83 \pm 0.5$ & $5.58 \pm 0.22$ \\
& 4.5 & $5.44 \pm 0.8$ & $5.11 \pm 0.2$ & $5.37 \pm 0.56$ & $6.72 \pm 0.26$ & $5.88 \pm 0.65$ & $5.03 \pm 0.6$ & $5.88 \pm 0.45$ & $5.13 \pm 0.24$ \\
& 6 & $4.89 \pm 0.6$ & $4.34 \pm 0.62$ & $5 \pm 0.36$ & $8.27 \pm 0.36$ & $7.25 \pm 0.23$ & $3.79 \pm 0.36$ & $7.25 \pm 0.32$ & $3.39 \pm 0.26$ \\
\hline 14 & 0 & $4.93 \pm 0.65$ & $4.21 \pm 0.6$ & $5.28 \pm .34$ & $1 \pm 0.2$ & $2.55 \pm 0.42$ & $4.18 \pm 0.9$ & $4.85 \pm 0.8$ & $4.28 \pm 0.3$ \\
& 1.5 & $5.69 \pm 0.3$ & $5.04 \pm 0.3$ & $5.37 \pm 0.65$ & $3.1 \pm 0.12$ & $4.25 \pm 0.32$ & $5.46 \pm 0.32$ & $3.45 \pm 0.6$ & $5.83 \pm 0.3$ \\
& 3 & $5.56 \pm 0.25$ & $5.29 \pm 0.25$ & $4.93 \pm 0.8$ & $4.17 \pm 0.88$ & $4.83 \pm 0.39$ & $4.71 \pm 0.5$ & $4.63 \pm 0.5$ & $5.28 \pm 0.36$ \\
& 4.5 & $5.14 \pm 0.5$ & $4.83 \pm 0.33$ & $5.87 \pm 0.3$ & $6.32 \pm 0.56$ & $5.18 \pm 0.55$ & $4.33 \pm 0.45$ & $6.88 \pm 0.18$ & $4.72 \pm 0.32$ \\
& 6 & $4.19 \pm 0.6$ & $4.14 \pm 0.22$ & $6.1 \pm 0.7$ & $8.01 \pm 0.4$ & $7.14 \pm 0.5$ & $3.09 \pm 0.8$ & $7.95 \pm 0.26$ & $3.11 \pm 0.26$ \\
\hline 28 & 0 & $4.53 \pm 0.2$ & $4.23 \pm 0.9$ & $5.78 \pm 0.2$ & $1 \pm 0.16$ & $2.05 \pm 0.24$ & $4.38 \pm 0.55$ & $5.15 \pm 0.52$ & $4.33 \pm 0.3$ \\
& 1.5 & $5.19 \pm 0.3$ & $5.14 \pm 0.7$ & $5.87 \pm 0.3$ & $3.23 \pm 0.18$ & $4.15 \pm 0.35$ & $5.76 \pm 0.32$ & $3.65 \pm 0.25$ & $5.13 \pm 0.62$ \\
& 3 & $5.06 \pm 0.8$ & $5.05 \pm 0.35$ & $5.23 \pm 0.9$ & $4.27 \pm 0.45$ & $4.63 \pm 0.85$ & $4.81 \pm 0.42$ & $4.83 \pm 0.8$ & $5.08 \pm 0.28$ \\
& 4.5 & $5.04 \pm 0.75$ & $4.53 \pm 0.75$ & $5.77 \pm 0.85$ & $6.02 \pm 0.35$ & $5.28 \pm 0.38$ & $4.83 \pm 0.4$ & $6.98 \pm 0.3$ & $4.22 \pm 0.32$ \\
& 6 & $4.19 \pm 0.38$ & $4.19 \pm 0.66$ & $6.61 \pm 0.78$ & $8.14 \pm 0.26$ & $7.64 \pm 0.44$ & $3.79 \pm 0.35$ & $8.25 \pm 0.6$ & $3.01 \pm 0.38$ \\
\hline
\end{tabular}

\section{Conclusions}

In conclusion, the addition of 1.5 or $3 \%$ of chia seeds to stirred yoghurts reduced postacidification and syneresis and improved viability and antioxidant activity of lactic acid bacteria during refrigerated storage. The sensory quality scores indicated that yoghurts enriched with 1.5 or $3 \%$ of seeds were appreciated. Effects of chia seeds are not dose dependent, since they are mucilaginous. Based on the obtained results, the utilisation of chia seeds in dairy industries would lead to a more convenient fermented milk product that satisfies consumers and provides health benefits due to its great nutritional contents.

The authors wish to acknowledge Research Unity of the High School of Food Industries (UR13-AGR 02) for supporting this research.

\section{References}

Alves Pires, M., Barros, J.C., Rodrigues, I., Sichetti Munekata, P.E. \& Trindade, M.A. (2020): Improving the lipid profile of bologna type sausages with Echium (Echium plantagineum L.) oil and chia (Salvia hispanica L.) flour. LWT - Food Sci. Technol., 119, 108907.

Cruz, A.G., Cavalcanti, R.N., Guerreiro, L.M.R., Sant’Ana, A.S., Nogueira, L.C., ... \& Bolini, H.M.A. (2013): Developing a prebiotic yogurt, rheological, physico-chemical and microbiological aspects and adequacy of survival analysis methodology. J. Food Eng., 114, 323-330.

DAS, K., CHOUdharY, R. \& THOMPSON-WitRicK, K.A. (2019): Effects of new technology on the current manufacturing process of yogurt-to increase the overall marketability of yogurt. LWT-Food Sci. Technol., 108, 6980. 
da Silva, H.L.A., Balthazar, C.F., Silva, R., Vieira, A.H., Costa, R.G.B., .. \& Cruz, A.G. (2018): Sodium reduction and flavor enhancer addition in probiotic prato cheese. Contributions of quantitative descriptive analysis and temporal dominance of sensations for sensory profiling. J. Dairy Sci., 101, 1-10.

de Falco, B., Amato, M. \& Lanzotti, V. (2017): Chia seeds products: An overview. Phytochem. Rev., 16, 745-760.

Donkor, O.N., Henriksson, A., Vasiljevic, T. \& Shah, N.P. (2005): Probiotic strains as starter cultures improve angiotensin-converting enzyme inhibitory activity in soy yoghurt. J. Food Sci., 70(8), 375-381.

Donmez, O., Mogol, B.A. \& Gokmen, V. (2017): Syneresis and rheological behaviors of set yogurt containing green tea and green coffee powders. J. Dairy Sci., 100, 901-907.

Downes, F.P. \& ITO, K. (EDS) (2001): Compendium of methods for microbiological examination of food. American Public Health Association (APHA), (4 ${ }^{\text {th }}$ ed.) Washington, DC.

Espírito Santo, A.P., Cartolano, N.S., Silva, T.F., Soares, F.A.S.M., Gioielli Luiz, A., ... \& Oliveira, M.N. (2012): Fibers from fruit by-products enhance probiotic viability and fatty acid profile and increase CLA content in yoghurts. Int. J. Food Microbiol., 154, 135-144.

Farkhandah, S., Umar, F., Afshan, S., Zafar, H., Kashif, A. \& Hafeez-Ur, R. (2019): Hypolipidaemic effects of synbiotic yoghurt in rabbits. Int. J. Dairy Technol., 72(4), 545-550.

Hadjimbei, E., Botsaris, G., Goulas, V., Alexandri, E., Gekas, V. \& Gerothanassis, I. (2020): Functional stability of goats' milk yoghurt supplemented with Pistacia atlantica resin extracts and Saccharomyces boulardii. Int J. Dairy Technol., 73(1), 134-143.

Hanato, T., Kagawa, H., Yasuhara, T. \& OKuda, T. (1988): Two new flavonoids and other constituents in licorice root: their relative astringency and radical scavenging effect. Chem. Pharm. Bull., 36, 1090-1097.

Janiaski, D.R., Pimentel, T.C., Cruz, A.G. \& Prudencio, S.H. (2016): Strawberry-flavored yogurts and whey beverages: What is the sensory profile of the ideal product? J. Dairy Sci., 99, 5273-5283.

Jenkins, A.L., Brissette, C., Jovanovski, E., Au-Yeung, F., Ho, H.V.T., .. \& \&Uuksan, V. (2016): Effect of salbachia (Salvia hispanica L.), an ancient seed, in the treatment of overweight and obese patients with type 2 diabetes: A double-blind, parallel, randomized controlled trial. FASEB J., 30, 126.2.

Jeong, C.H., Ryu, H., Zhang, T., Lee, C.H., Seo, H.G. \& Han, S.G. (2018): Green tea powder supplementation enhances fermentation and antioxidant activity of set-type yogurt. Food Sci. Biotechnol., 27, 1419-1427.

Khaledabad, M.A., Ghasempour, Z., Kia, E.M. \& Bari, R.Z. (2020): Probiotic yoghurt functionalised with microalgae and Zedo gum: Chemical, microbiological, rheological and sensory characteristics. Int. J. Dairy Technol., 73(1), 67-75.

Muñoz-Tébar, N., De la Vara, J.A., Ortiz de Elguea-Culebras, G., Cano, E.L., Molina, A. ... \& Berruga, M.I. (2019): Enrichment of sheep cheese with chia (Salvia hispanica L.) oil as a source of omega-3. LWT Food Sci. Technol., 108, 407-415.

Oh, N.S, Lee, J.Y., Joung, J.Y.K., Kim., S., Shin, Y.K., ... \& Kim, Y. (2016): Microbiological characterization and functionality of set-type yogurt fermented with potential prebiotic substrates Cudraniatricus pidata and Morus alba L. leaf extracts. J. Dairy Sci., 99, 6014-6025.

Pigni, N.B., Aranibar, C., Mas, A.L., Aguirre, A., ... \& Baroni, V.M. (2020): Chemical profile and bioaccessibility of polyphenols from wheat pasta supplemented with partially-deoiled chia flour. LWT - Food Sci. Technol., 124, 109-134.

Pinto, L.P.F., Silva, H.L.A., Kuriya, S.P., MaÇaira, P.M., Oliveira F.L.C., .. \& Freitas, M.Q. (2018): Understanding perceptions and beliefs about different types of fermented milks through the application of projective techniques: A case study using Haire's shopping list and free word association. J. Sens. Stud., 33(1), e12326.

Salgado-Cruz, M., Calderón-Domínguez, G., Chanona-Pérez, J., Farrera-Rebollo, R.R., Mendez-Mendez, J.V. \& Díaz-Ramírez, M. (2013): Chia (Salvia hispanica L.) seed mucilage release characterization - A microstructural and image analysis study. Ind. Crop. Prod., 51, 453-462.

Shafi, A., Raja, H.R., Farooq, U., Akram, K., Hayat, Z., .. \& Nadeem, H.R. (2019): Antimicrobial and antidiabetic potential of synbiotic fermented milk: A functional dairy product. Int. J. Dairy Technol., 72(1), 15-22.

Soares, E.K.B., Silva, R., Da Silva, W.P., Kuriya, S.P, MaÇAira, P.M., ... \& Esmerino, E.A. (2020): An intracultural investigation in Brazil using Coalho cheese and preferred attribute elicitation. J. Sens. Stud., 35(1), e12543.

SupavititPatana, P., Wirjantoro, T. \& Raviyam, P. (2010): Characteristics and shelf-life of corn milk yoghurt. CMU J. Nat. Sci., 9, 133-147

Torres, F.R., Esmerino, E.A., Thomas Carr, B., Ferrão, L.L., Granato, D., ... \& Cruz, A.G. (2017): Rapid consumer-based sensory characterization of requeijão cremoso, a spreadable processed cheese: Performance of new statistical approaches to evaluate check-all-that-apply data, J. Dairy Sci., 100(8), 6100-6110. 